\title{
New Cytotoxic Pregnane-type Steroid from the Stem Bark of Aglaia elliptica (Meliaceae)
}

\author{
Kindi Farabi $\odot^{1}$, Desi Harneti ${ }^{1}$, Nurlelasari $\odot^{1}$, Rani Maharani $\odot^{1}$, \\ Ace Tatang Hidayat ${ }^{1,2}$, Khalijah Awang ${ }^{3}$, Unang Supratman ${ }^{1,2, *}$ and \\ Yoshihito Shiono ${ }^{4}$
}

${ }^{1}$ Department of Chemistry, Faculty of Mathematics and Natural Sciences, Universitas Padjadjaran, Jatinangor 45363, Sumedang, Indonesia

${ }^{2}$ Central Laboratory of Universitas Padjadjaran, Jatinangor 45363, Sumdeang, Indonesia

${ }^{3}$ Department of Chemistry, Faculty of Science, University of Malaya, Kuala Lumpur 59100, Malaysia

${ }^{4}$ Department of Food, Life, and Environmental Science, Faculty of Agriculture, Yamagata University,

Tsuruoka, Yamagata 997-8555, Japan

(Received July 5, 2017; Revised September 13, 2017; Accepted September 13, 2017)

\begin{abstract}
A new pregnane-type steroid, $2 \alpha$-hydroxy-3 $\alpha$-methoxy-5 $\alpha$-pregnane (1), together with three known

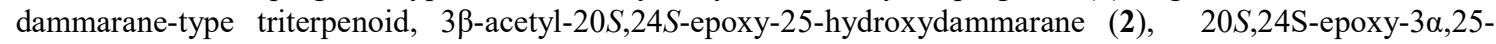
dihydroxydammarane (3), and eichlerianic acid (4) have been isolated from the stem bark of Aglaia elliptica. The structures were determined by spectroscopic methods including the 2D-NMR techniques. Compound 1-4 showed moderate cytotoxic activity against P-388 murine leukemia cells.
\end{abstract}

Keywords: Pregnane-type steroid; Aglaia elliptica; cytotoxic activity; Meliaceae. (C) 2018 ACG Publications. All rights reserved.

\section{Introduction}

Aglaia is the largest genus belong to Meliaceae family contain about 150 species, and more than 65 species of them were grown in Indonesia [1,2]. Recently, Aglaia genus used traditionally for treatment some desease. In Thailand, A. odorata used for the treatment of traumatic injury, bruises, febrifuge, heart disease and toxin by causing vomiting [3] and the bark of $A$. eximia used by Indonesian people for treating coughs, skin, reducing fever, and contused wound [4]. This genus distributed in Indo-Malaysian region, especially in tropical and subtropical forest [1]. Previous phytochemical investigation in this genus reported contain interesting secondary metabolites with biological activity, including antifungal and antitumor sesquiterpenoid [5,6], cytotoxic and antiinflammatory diterpenoid [7], cytotoxic and anti-retroviral triterpenoid [3,8-11], cytotoxic steroid [4], cytotoxic alkaloid [12,13], anti-inflammatory and cytotoxic rocaglamide [14-16]. During the course of our continuing search for anticancer compounds from Indonesia Aglaia plant, the methanolic extract

\footnotetext{
*Corresponding author: E Mail: unang.supratman@unpad.ac.id; Phone/Fax: +62-22-7794391
} 
from the stembark of Aglaia elliptica showed moderate cytotoxic activity against P-388 murine leukemia cells. A. elliptica is a rain forest plant, mainly distributed in some part in Kalimantan island in central part of Indonesia [17]. This plant has been used as traditional medicine for healing of tumor, skin and contused wound diaseases [18]. Previous phytochemical study from this plant reported the presence of diamide and cycloartane-type triterpenoid from leaves [19] and cytotoxic $1 \mathrm{H}$ cyclopenta[b]benzofuran from fruits [18]. Herein, we describe the isolation and structure

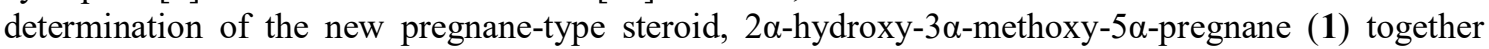
with the cytotoxic activity of compounds 1-4 against P-388 murine leukemia cells.

\section{Materials and Methods}

\subsection{General}

Optical rotation was recorded on a Perkin-Elmer 341 (Waltham, MA, USA). Melting points were measured on IA9000 electrothermal melting point (Bibby Scientific Limited, Staffordshire, UK). The IR spectra were recorded on a 1760X Perkin-Elmer FT-IR using $\mathrm{KBr}$ as pellet (Waltham, MA, USA). Mass spectra were obtained with a HR-MS XEV ${ }^{\text {otm }}$ Water Qtof mass spectrometer (Waters, MA, USA). ${ }^{1} \mathrm{H}$ - and ${ }^{13} \mathrm{C}-\mathrm{NMR}$ spectra were measured with a JEOL ECZ-600 and JEOL JNM A-500 spectrometer (Tokyo, Japan) using TMS as an internal standard. Column chromatography was conducted on silica gel 60 (Kanto Chemical Co., Inc., Japan) and Sephadex LH-20 (Sigma-Aldrich). TLC plates with silica gel $\mathrm{GF}_{254}$ (Merck, $0.25 \mathrm{~mm}$ ) and compound detection by spraying with $10 \%$ $\mathrm{H}_{2} \mathrm{SO}_{4}$ in ethanol, continued by heating.

\subsection{Plant Material}

The stem bark of A. elliptica were obtained in Bogor Botanical Garden, West Java, Indonesia in June 2015. The plant was identified and classified by the staff of Herbarium Bogoriense, Indonesia and a voucher specimen (No. Bo-1294562) was deposited at the herbarium.

\subsection{Extraction and Isolation}

The crushed and dried powder of stem bark of A. elliptica $(2.3 \mathrm{~kg})$ was macerated with methanol $(12 \mathrm{~L} \times 5)$ at room temperature. After removing the solvent in vacuum condition, the dark brown concentrated of $\mathrm{MeOH}$ extract ( $321.5 \mathrm{~g}$ ) was obtained. This extract was first dissolved in $\mathrm{H}_{2} \mathrm{O}$ and partitioned with $n$-hexane, EtOAc, and $n$-butanol, respectively. The $n$-hexane fraction $(22.6 \mathrm{~g})$ was fractionated by vacuum liquid chromatography on silica gel using a gradient combination of $n$-hexane and EtOAc (10:0, 9.5:0.5, 9:1, 8.5:1.5,,...,0:10). Based on TLC analyses, similar fractions were combined to yield five main fractions (A-E). Fraction C (5 g) was separated on a chromatography column of silica gel, eluted with a combination of gradient of $n$-hexane-EtOAc (10:0-1:1), to give five subfractions (C1-C5). Subfraction $\mathrm{C} 2$ was separated on a chromatography column of silica gel, eluted with $n$-hexane-EtOAc (10:0-5:5), to give three subfractions (C2A-C2C). Subfraction C2B was separated on a preparative TLC, eluted with combination of $n$-hexane-EtOAc (8.5:1.5), to give 2 (10.3 $\mathrm{mg}$ ). Subfraction C5 was separated on a chromatography column of silica gel, eluted with $n$-hexaneEtOAc (10:0-7:3), to give three subfractions (C5A-C5C). Subfraction C5B was recrystallized in $\mathrm{MeOH}$, to give $3(19.5 \mathrm{mg})$. The EtOAc soluble fraction $(20 \mathrm{~g})$ was fractionated by column chromatography on silica gel using a gradient combination of $n$-hexane and EtOAc to give fractions F-J. Fraction F (627 mg) was separated on a chromatography column of silica gel, eluted with $\mathrm{CHCl}_{3}-$ EtOAc (10:0-7:3), to give four subfractions (F1-F4). Subfraction F4 was chromatographed on sephadex LH-20, eluted with $\mathrm{CHCl}_{3}-\mathrm{MeOH}(7: 3)$, to give $4(119.2 \mathrm{mg})$. Fraction $\mathrm{H}(1.76 \mathrm{~g})$ was chromatographed on a column of silica gel, eluted with $\mathrm{CHCl}_{3}-\mathrm{MeOH}$ (10:0-7:3), to give seven subfractions $(\mathrm{H} 1-\mathrm{H} 7)$. Subfraction $\mathrm{H} 2$ was separated on a preparative TLC, eluted with $\mathrm{CHCl}_{3}-\mathrm{EtOAc}$ (5:5), to give 1 (5 mg). 


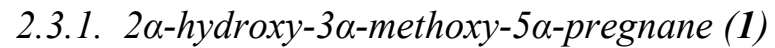

Colorless oil; $[\alpha]_{20}^{\mathrm{D}}+17.1^{\circ}\left(c, 0.3, \mathrm{CHCl}_{3}\right)$; IR (KBr) $v_{\max } 3403,2980,1067,1073 \mathrm{~cm}^{-1} .{ }^{1} \mathrm{H}$ NMR $\left(\mathrm{CDCl}_{3}, 600 \mathrm{MHz}\right)$, see Table $1 ;{ }^{13} \mathrm{C}$ NMR $\left(\mathrm{CDCl}_{3}, 150 \mathrm{MHz}\right)$, see Table 1; HR-ESI-TOFMS (negative ion mode) $m / z 333.2425$ [M-H]', (calcd. for $\mathrm{C}_{22} \mathrm{H}_{38} \mathrm{O}_{2}, \mathrm{~m} / z$ 334.2422).

\subsection{Determination of Cytotoxic Activities}

The P388 murine leukemia cells were seeded into 96-well plates at an initial cell density of approximately $3 \times 10^{4}$ cells $\mathrm{cm}^{-3}$. After $24 \mathrm{~h}$ incubation for cell attachment and growth, variation concentration of samples were added. The compounds in DMSO solvent added at the required concentration. Subsequent six desirable concentrations were prepared using PBS (phosphoric buffer solution, $\mathrm{pH}=7.30-7.65)$, the negative control is only DMSO. After a $48 \mathrm{~h}$ incubation periode, the assay was terminated by adding MTT reagent [3-(4,5-dimethylthiazol-2-yl)-2,5-diphenyl tetrazolium bromide] and the incubation was continued for another $4 \mathrm{~h}$, in which the MTT-stop solution containing SDS (sodium dodecyl sulphate) was added and another $24 \mathrm{~h}$ incubation was conducted using a micro plate reader at $550 \mathrm{~nm}$, optical density was read, the plotted graph of percentage live cells compared to control (\%), receiving only PBS and DMSO, versus the tested concentration of compounds will give the $\mathrm{IC}_{50}$ values in $\mu \mathrm{g} / \mathrm{mL}$. The $\mathrm{IC}_{50}$ value is the concentration required for $50 \%$ growth inhibition. Each experiment was run in triplicate and averaged.
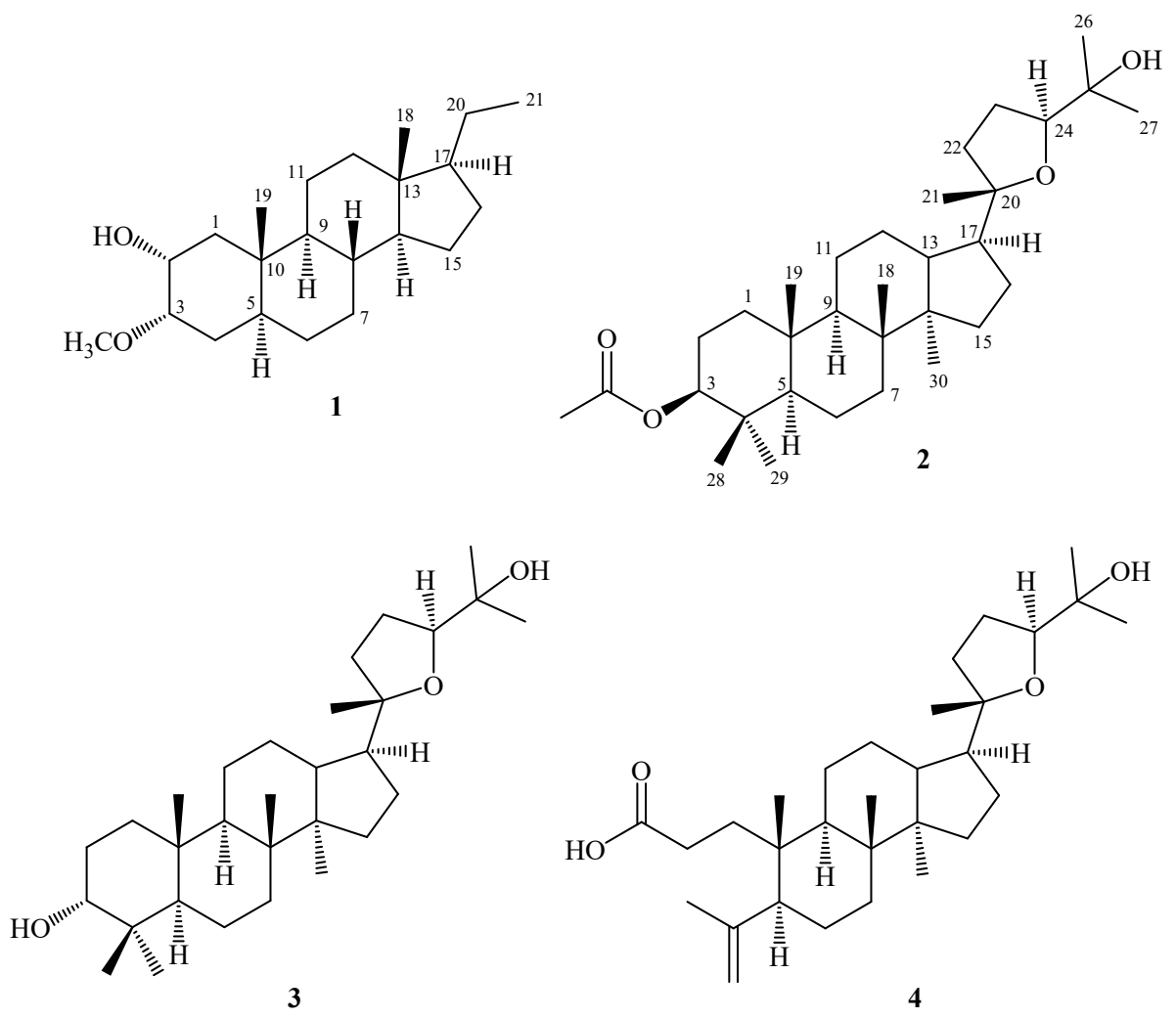

Figure 1. Structures of compounds 1-4. 


\section{Results and Discussion}

\subsection{Structure Elucidation}

Compound 1 was a colorless oil form, with $[\alpha]^{\mathrm{D}}{ }_{20}+17.1^{\circ}\left(c 0.3, \mathrm{CHCl}_{3}\right)$. The molecular composition is determined as $\mathrm{C}_{22} \mathrm{H}_{38} \mathrm{O}_{2}$, from the HR-TOF-MS with molecular ion peak found $\mathrm{m} / \mathrm{z}$ 333.2425 [M-H]', (calcd. for $\mathrm{C}_{22} \mathrm{H}_{38} \mathrm{O}_{2}, \mathrm{~m} / z$ 334.2422) and together with NMR data (Table 1). The IR spectrum showed the functional group of a hydroxyl $\left(3403 \mathrm{~cm}^{-1}\right)$ and ether groups (1067 and 1073 $\mathrm{cm}^{-1}$ ). In ${ }^{13} \mathrm{C}$ NMR spectrum, its resonated of 22 carbons, which were classified as 4 methyl (one methoxy), 9 methylenes, 7 methines (two oxygenated), and 2 quarternary carbons. This molecule have four degrees of unsaturation, which consistent with tetracyclic pregnane-type steroid skeleton. The presence of singlets of two tertiary methyls $\left(\delta_{\mathrm{H}} 0.67\right.$ and 0.86 , each $\left.3 \mathrm{H}\right)$, one primary methyl $\left(\delta_{\mathrm{H}} 1.00\right.$, $3 \mathrm{H})$, one methoxy $\left(\delta_{\mathrm{H}} 3.95,3 \mathrm{H}\right)$, and two oxymethine protons $\left(\delta_{\mathrm{H}} 3.60\right.$ and 3.40 , each $\left.1 \mathrm{H}\right)$ were observed in ${ }^{1} \mathrm{H}$ NMR spectrum and supported the presence of pregnane-type steroid skeleton of compound 1. The spectral data of $\mathbf{1}$ was similar to aglatomin A, isolated from A. tomentosa [20], except the absence of carbonyl ketone and different position of hydroxy and methoxy groups in $\mathbf{1}$. The confirmed structure of 1 was obtained from the $\mathrm{HMBC}$ and ${ }^{1} \mathrm{H}-{ }^{1} \mathrm{H}$ COSY experiments (Figure 2). The skeleton of pregnan-type steroid was determined by HMBC correlation of tertiary methyls. The correlation of $\mathrm{CH}_{3}-19\left(\delta_{\mathrm{H}} 0.86\right)$ to $\mathrm{C}-1\left(\delta_{\mathrm{C}} 44.9\right), \mathrm{C}-5\left(\delta_{\mathrm{C}} 54.2\right), \mathrm{C}-10\left(\delta_{\mathrm{C}} 37.7\right)$ and $\mathrm{C}-9\left(\delta_{\mathrm{C}} 38.6\right)$ and correlation of $\mathrm{CH}_{3}-18\left(\delta_{\mathrm{H}} 0.67\right)$ to $\mathrm{C}-12\left(\delta_{\mathrm{C}} 38.2\right), \mathrm{C}-13\left(\delta_{\mathrm{C}} 42.2\right), \mathrm{C}-14\left(\delta_{\mathrm{C}} 50.5\right)$ and $\mathrm{C}-17\left(\delta_{\mathrm{C}} 65.4\right)$, showed the characteristic of tetracyclic core of pregnane-type steroid [21]. The presence of ethyl group in side chain of $\mathbf{1}$, was proved by typical of ${ }^{1} \mathrm{H}$ NMR of primary methyl $\mathrm{CH}_{3}-21\left(\delta_{\mathrm{H}} 1.00, \mathrm{t}, J=\right.$ $6.6 \mathrm{~Hz})$ and $\mathrm{HMBC}$ correlation between $\mathrm{CH}_{3}-21\left(\delta_{\mathrm{H}} 1.00\right)$ to $\mathrm{C}-20\left(\delta_{\mathrm{C}} 17.7\right)$ and $\mathrm{C}-17\left(\delta_{\mathrm{C}} 65.4\right)$, this correlation also indicated that the ethyl group was linked at $\mathrm{C}-17$. The absence of ketone group at $\mathrm{C}-16$ in 1 , instead the presence of typical methylene group at $\delta_{\mathrm{H}} 1.25\left(\delta_{\mathrm{C}} 44.8\right)$. The position of hydroxy and methoxy groups were proved by $\mathrm{HMBC}$ and ${ }^{1} \mathrm{H}-{ }^{1} \mathrm{H}$ COSY correlations. HMBC cross peak which observed between $\mathrm{H}-1\left(\delta_{\mathrm{H}} 2.00\right)$ to oxymethine at C-2 $\left(\delta_{\mathrm{C}} 73.0\right)$ and $\mathrm{C}-3\left(\delta_{\mathrm{C}} 76.4\right)$, and COSY correlation between $\mathrm{H}-1 / \mathrm{H}-2 / \mathrm{H}-3 / \mathrm{H}-4$ suggested that the oxymethines were located at position $\mathrm{C}-2$ and C-3, respectively. Position of methoxy group at C-3 established from correlation at methoxyl signal at $\delta_{\mathrm{H}} 3.95$ to $\mathrm{C}-3\left(\delta_{\mathrm{C}} 76.4\right)$, consequently, the hydroxy group was attached at C-2. Configuration of $5 \alpha$ was proved by the upfield shift of $\mathrm{CH}_{3}-19$ [22] and the NOESY correlation $\mathrm{H}-5 \alpha / \mathrm{H}-4 \alpha$. The NOESY experiment confirmed the configuration of $\mathrm{H}-14 \alpha$ and $\mathrm{H}-17 \alpha$, which was the usual configurations from pregnane derivatives. Finally the H-2 $\beta$ and $\mathrm{H}-3 \beta$ configurations were deduced from the cross peaks of NOESY H-2/H-19 and H-2/H-3 (Figure 2). Therefore, the structure of new pregnane-type steroid, $2 \alpha-$ hydroxy-3 $\alpha$-methoxy-5 $\alpha$-pregnane was thus elucidated to be $\mathbf{1}$.

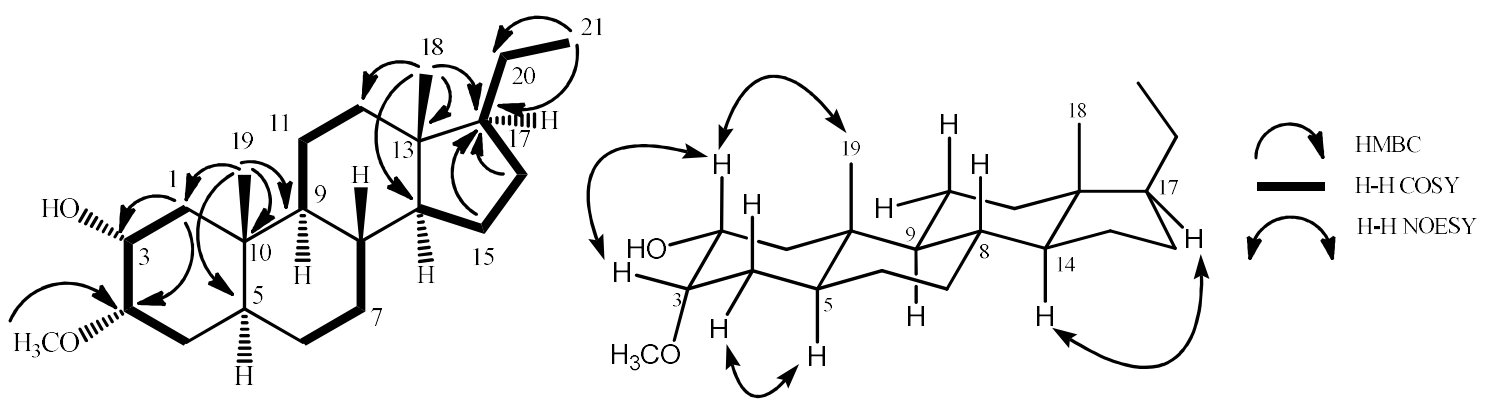

Figure 2. Selected HMBC, ${ }^{1} \mathrm{H}-{ }^{1} \mathrm{H}$ COSY, and ${ }^{1} \mathrm{H}-{ }^{1} \mathrm{H}$ NOESY correlations for $\mathbf{1}$.

The known compounds 3 3 -acetyl-20S,24S-epoxy-25-hydroxydammarane (2) [23], 20S,24Sepoxy-3 $\alpha, 25$-dihydroxydammarane (3) [23], and eichlerianic acid (4) [23], were confirmed by comparison and biogenetic analysis of these compounds with reported values. 


\subsection{Cytotoxic Activity}

The cytotoxicity values of the four isolated compounds 1-4 against the P388 murine leukemia cells were conducted based on experiment in previous paper $[8,24,25]$ and artonin $\mathrm{E}\left(\mathrm{IC}_{50} 0.75 \mu \mathrm{g} / \mathrm{mL}\right)$ used as a positive control [26].

Compounds 1-4 were evaluated for their cytotoxicity against the P-388 murine leukemia cells and showed $\mathrm{IC}_{50}$ values of $6.07 \pm 0.02,4.09 \pm 0.09,11.03 \pm 0.10$, and $5.59 \pm 0.10 \mu \mathrm{g} / \mathrm{mL}$, respectively. Among those isolated compound, 3 $\beta$-acetyl-20S,24S-epoxy-25-hydroxydammarane (2) showed strongest activity whereas eichlerianic acid (4) having open chain A-ring showed stronger activity than 20S,24S-epoxy-3 $\alpha, 25$-dihydroxydammarane (3) suggested that acetyl group and open chan Aring in dammarane-type triterpenoids may be play an important role for cytotoxic activity.

Table 1. NMR Data (600 MHz for ${ }^{1} \mathrm{H}$ and $150 \mathrm{MHz}$ for ${ }^{13} \mathrm{C}$, in $\mathrm{CDCl}_{3}$ ) for $\mathbf{1}$.

\begin{tabular}{|c|c|c|}
\hline Position & $\begin{array}{l}{ }^{13} \mathrm{C} \text { NMR } \\
\delta \mathrm{c} \text { (mult.) }\end{array}$ & $\begin{array}{c}{ }^{1} \mathrm{H} \text { NMR } \\
\delta_{\mathrm{H}}(\text { Integral, mult., } J=\mathrm{Hz})\end{array}$ \\
\hline 1 & $44.9\left(\mathrm{CH}_{2}\right)$ & $2.00(2 \mathrm{H}, \mathrm{dd}, 4.2,12.8)$ \\
\hline 2 & $73.0(\mathrm{CH})$ & $3.60(1 \mathrm{H}, \mathrm{m})$ \\
\hline 3 & $76.4(\mathrm{CH})$ & $3.40(1 \mathrm{H}, \mathrm{m})$ \\
\hline 4 & $35.9\left(\mathrm{CH}_{2}\right)$ & $1.90(2 \mathrm{H}, \mathrm{m})$ \\
\hline 5 & $54.2(\mathrm{CH})$ & $0.90(1 \mathrm{H}, \mathrm{m})$ \\
\hline 6 & $27.7\left(\mathrm{CH}_{2}\right)$ & $\begin{array}{l}1.12(1 \mathrm{H}, \mathrm{m}) \\
1.17(1 \mathrm{H}, \mathrm{m})\end{array}$ \\
\hline 7 & $32.1\left(\mathrm{CH}_{2}\right)$ & $\begin{array}{l}1.63(1 \mathrm{H}, \mathrm{m}) \\
2.02(1 \mathrm{H}, \mathrm{m})\end{array}$ \\
\hline 8 & $33.9(\mathrm{CH})$ & $1.50(1 \mathrm{H}, \mathrm{m})$ \\
\hline 9 & $38.6(\mathrm{CH})$ & $1.30(1 \mathrm{H}, \mathrm{m})$ \\
\hline 10 & $37.7(\mathrm{C})$ & - \\
\hline 11 & $20.9\left(\mathrm{CH}_{2}\right)$ & $\begin{array}{l}1.04(1 \mathrm{H}, \mathrm{m}) \\
1.35(1 \mathrm{H}, \mathrm{m})\end{array}$ \\
\hline 12 & $38.2\left(\mathrm{CH}_{2}\right)$ & $1.37(2 \mathrm{H}, \mathrm{m})$ \\
\hline 13 & $42.2(\mathrm{C})$ & - \\
\hline 14 & $50.5(\mathrm{CH})$ & $1.40(1 \mathrm{H}, \mathrm{m})$ \\
\hline 15 & $35.6\left(\mathrm{CH}_{2}\right)$ & $1.65(2 \mathrm{H}, \mathrm{m})$ \\
\hline 16 & $44.8\left(\mathrm{CH}_{2}\right)$ & $1.25(2 \mathrm{H}, \mathrm{m})$ \\
\hline 17 & $65.4(\mathrm{CH})$ & $1.63(1 \mathrm{H}, \mathrm{m})$ \\
\hline 18 & $13.6\left(\mathrm{CH}_{3}\right)$ & $0.67(3 \mathrm{H}, \mathrm{s})$ \\
\hline 19 & $13.5\left(\mathrm{CH}_{3}\right)$ & $0.86(3 \mathrm{H}, \mathrm{s})$ \\
\hline 20 & $17.7\left(\mathrm{CH}_{2}\right)$ & $1.68(2 \mathrm{H}, \mathrm{m})$ \\
\hline 21 & $13.6\left(\mathrm{CH}_{3}\right)$ & $1.00(3 \mathrm{H}, \mathrm{t}, 6.6)$ \\
\hline 3-OMe & $56.6\left(\mathrm{CH}_{3}\right)$ & $3.95(3 \mathrm{H}, \mathrm{s})$ \\
\hline
\end{tabular}

\section{Acknowledgments}

This investigation was financially supported by Directorate General of Higher Education, Ministry of Research, Technology and Higher Education, Indonesia (Postgraduate Grant, 2015-2016 by US). We thank Mrs. Suzany Dwi Elita at Department of Chemistry, Faculty of Mathemathics and Natural Sciences, Institute Technology Bandung, Indonesia for cytotoxicity bioassay.

\section{Supporting Information}

Supporting information accompanies this paper on http://www.acgpubs.org/RNP 


\section{ORCID}

Kindi Farabi: 0000-0001-5552-3827

Desi Harneti: 0000-0002-8120-7892

Nurlelasari: 0000-0002-9317-2607

Rani Maharani: 0000-0002-4832-7227

Ace Tatang Hidayat: 0000-0002-6960-3825

Khalijah Awang: 0000-0001-5971-6570

Unang Supratman: 0000-0003-1104-2321

Yoshihito Shiono: 0000-0002-9303-0182

\section{References}

[1] C. M. Pannell. Taxonomic monograph of the genus Aglaia lour (Meliaceae). Kew Bulletin Additional. Series XVI. (Kew, Richmond, 1992) pp. 359-362.

[2] D. L. Wood, R. M. Silverstain and M. Nakajima (1970). Control of Insects Behavior by Natural Product. Academic Press. New York.

[3] O. Yodsaoue, J. Sonprasit, C. Karalai, C. Ponglimanont, S. Tewtrakul and S. Chantrapromma (2012). Diterpenoids and triterpenoids with potential anti-inflammatory activity from the leaves of Aglaia odorata, Phytochemistry 76, 83-91.

[4] D. Harneti, A. Supriadin, M. Ulfah, A. Safari, U. Supratman, K. Awang and H. Hayashi (2014). Cytotoxic constituents from the bark of Aglaia eximia (Meliaceae), Phytochem. Lett. 8, 28-31.

[5] N. Joycharat, P. Plodpai, K. Panthong, B. Yingyongnarongkul and S. P. Voravuthikunchai (2010). Terpenoid constituents and antifungal activity of Aglaia forbesii seed against phytopathogens, Can. J. Chem. 88, 937-944.

[6] S. Liu, S. B. Liu, W. Zuo, Z. Guo, W. Mei and H. Dai (2014). New sesquiterpenoids from Aglaia odorata var. Microphyllina and their cytotoxic activity, Fitoterapia 92, 93-99.

[7] X. Cai, Y. Wang, P. Zhao, Y. Li and X. Luo (2010). Dolabellane diterpenoids from Aglaia odorata, Phytochemistry 71, 1020-1024.

[8] D. Harneti, R. Tjokronegoro, A. Safari, U. Supratman, X. Loong, M. R. Mukhtar, K. Mohamad, K. Awang and H. Hayashi (2012). Cytotoxic triterpenoids from the bark of Aglaia smithii (Meliaceae), Phytochem. Lett. 5, 496-499.

[9] F. Zhang, J. Wang, Y. Gu and Y. Kong (2010). Triterpenoids from Aglaia abbreviata and their cytotoxic activities, J. Nat. Prod. 73, 2042-2046.

[10] K. Awang, X. Loong, K. H. Leong, U. Supratman, M. Litaudon, M. R. Mukhtar and K. Mohamad (2012). Triterpenes and steroids from the leaves of Aglaia exima (Meliaceae), Fitoterapia 83, 13911395.

[11] C. O. Esimone, G. Eck, C. S. Nworu, D. Hoffmann, K. Uberla and P. Proksch (2010). Dammarenolic acid, a secodammarane triterpenoid from Aglaia $s p$. shows potent anti-retroviral activity in vitro, Phytomedicine 17, 540-547.

[12] J. Sianturi, M. Purnamasari, Darwati, D. Harneti, T. Mayanti, U. Supratman, K. Awang and H. Hayashi (2015). New bisamide compounds from the bark of Aglaia eximia (Meliaceae), Phytochem. Lett. 13, 297-301.

[13] S. Wang, Y. Cheng and C. Duh (2001). Cytotoxic constituents from leaves of Aglaia elliptifolia, J. Nat. Prod. 64, 92-94.

[14] Y. Chin, H. Chae, J. Lee, T. T. Bach, K. Ahn, H. Lee, H. Joung and S. Oh (2010). Bisamides from the twigs of Aglaia perviridis collected in Vietnam, Bull. Korean. Chem. Soc, 31(9), 2665-2667.

[15] L. Pan, L. B. S. Kardono, S. Riswan, H. Chai, E. J. C. Blanco, C. M. Pannell, D. D. Soejarto, T. G. McCloud, D. J. Newman and A. D. Kinghorn (2010). Isolation and characterization of minor analogues of silvestrol and other constituents from large-scale re-collection of Aglaia foveolata, J. Nat. Prod. 73, 1873-1878.

[16] S. Wang, Y. Cheng and C. Duh (2001). Cytotoxic constituents from leaves of Aglaia elliptifolia, J. Nat. Prod. 64, 92-94.

[17] A. N. Muellner, R. Samuel, M. W. Chase, C. M. Pannell and H. Greger (2005). Aglaia (Meliaceae): an evaluation of taxonomic concepts based on DNA data and secondary metabolites, Amer. J. Bot. 92(3), 534-543.

[18] B. Cui, H. Chai, T. Santisuk, V. Reutrakul, N. R. Farnsworth, G. A. Cordell, J. M. Pezzuto and A. D. Kinghom (1997). Novel cytotoxic $1 H$-cyclopenta[b]benzofuran lignans from Aglaia elliptica, Tetrahedron 53(52), 17625-17632. 
[19] A. Inada, T. Sorano, H. Murata, Y. Inatomi, D. Darnaedi and T. Nakanishi (2001). Diamide derivatives and cycloartanes from the leaves of Aglaia elliptica, Chem. Pharm. Bull. 49(9), 1226-1228.

[20] K. Mohamad, T. Sevenet, V. Dumontet, M. Pais, M. V. Trib, H. Hadi, K. Awang and M. Martin (1999). Dammarane triterpenes and pregnane steroids from Aglaia lawii and A. tomentosa, Phytochemistry 51, 1031-1037.

[21] H. Inada, H. Murata, Y. Inatomi, T. Nakanishi and D. Darnaedi (1997). Pregnanes and triterpenoid hydroperoxydes from the leaves of Aglaia grandis, Phytochemistry 45(6), 1225-1228.

[22] T. Hung, H. Stuppner, E. P. Ellmere-Muller, D. Sholz, D. Eigner and M. P. Manandhar (1995). Steroids and terpenoids from the gum resin of Ailanthus grandis, Phytochemistry 39, 1403-1409.

[23] D. Roux, M. T. Martin, M. T. Adeline, T. Sevenet, A. H. A. Hadi and M. Pais (1998). Foveolins A and B, dammarane triterpenes from Aglaia foveolata, Phytochemistry 49(6), 1745-1748.

[24] H. E. H. Sahidin, L. D. Juliawaty, Y. M. Syah, L. B. Din, E. L. Ghisalberti, J. Latip, I. M. Said and S. A. Achmad (2005). Cytotoxic properties of oligostilbenoids from the tree bark of Hopea dryobalanoides, Z. Naturforsch. 60c, 723-727.

[25] M. C. Alley, D. A. Scudiero, A. Monks, M. L. Hursey, M. J. Czerwinski, D. L. Fine, B. J. Abbott, J. G. Mayo, R. H. Shoemaker and M. R. Boyd (1988). Feasibility of drug screening with panels of tumor cell lines using a microculture tetrazolium assay, Cancer Res. 48, 589-601.

[26] E. H. Hakim, S. A. Achmad, L. D. Juliawaty, L. Makmur, Y. M. Syah, A. Aimi, M. Kitajima, H. Takayama and E. L. Ghisalberti (2007). Prenylated flavonoids and related compounds of the Indonesian Artocarpus (Moraceae), J. Nat. Med. 61(2), 229-236.

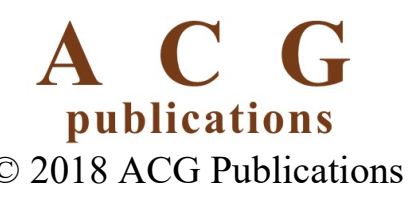

